\title{
Konsep Desain Venakular Dalam Bentuk pagawéan barudak di Baduy-Dalam
}

\author{
Mohamad Zaini Alif \\ Institut Seni Budaya Indonesia (ISBI) Bandung \\ Jalan Buah Batu No.212 Bandung 40265 \\ Agus Sachari, Setiawan Sabana \\ Institut Teknologi Bandung (ITB) Bandung \\ Jalan Ganesha 10 Bandung
}

\begin{abstract}
The term, Toys and Games in Inner Baduy society, are not familiar. They recognize them as Pagawéan Barudak. It is action using tools as media. The study was conducted in Inner Baduy, which focused on three villages, named Cibeo, Cikeusik and Cikartawana. The toys and games design in Baduy is a process of transmitting moral, and socialization skills. Its form is presented through the study of vernacular design, which explains how the value of the transmission processes. In the pagawean barudak, determination and obedience are delivered through skills (skills training) in making, using it, obedience is delivered through the use of materials, forms, processes and the results of it. In the making process of the creation in pagawéan barudak portrays relationship of human being with the needs of surrounding nature. Then, those needs will be filled with rules, which are interconnected between them and the environment, emerging pikukuh and pitutur that must be followed in conducting all activity.
\end{abstract}

Keyword: Design, Vernacular, Toys, Inner Baduy.

\begin{abstract}
ABSTRAK
Istilah Mainan dan Permainan di masyarakat Baduy, tidak dikenal. Mereka menyebutnya Pagawéan Barudak, ini merupakan hasil kegiatan dengan menggunakan alat sebagai medianya. Penelitian dilakukan di Baduy, difokuskan ke tiga kampung, yaitu Cibeo, Cikeusik dan Cikartawana. Desain Mainan dan permainan di Baduy, adalah proses transmisi keterampilan, moral, dan sosialisasi. Bentuknya yang disajikan melalui studi desain vernakular yang akan menjelaskan bagaimana nilai dari proses transmisi itu berlangsung. Pada barudak melakukanpagawean, keteguhan dan kepatuhan disampaikan melalui keterampilan (skill training) dalam membuat, menggunakan pagawean barudak, kepatuhan disampaikan melalui penggunaan bahan, bentuk, proses dan hasil pagawean barudak. Dalam proses pembuatan produk dalam bentuk pagawéan barudak adalah, hubungan manusia dengan kebutuhan alam sekitarnya. Kemudian, kebutuhan tersebut akan dipenuhi oleh aturan yang saling berhubungan antara mereka dan lingkunganya, sehingga lahir pikukuh dan pitutur yang harus diikuti dalam melakukan seluruh kegiatanya.
\end{abstract}

Kata kunci : Desain, Vernacular, Mainan, Baduy-Dalam 


\section{PENDAHULAUAN}

Mainan tradisional di masyarakat merupakan salah satu contohmodel pengetahuan masyarakat tradisi. Model tradisi yang diyakini kebenaran informasinya akan dibangun dan dipertahankan terus menerus, sehingga dapat dijadikan pedoman (pikukuh dan pitutur). Pedoman untuk prilaku ini dipakai untuk memenuhi kebutuhan hidup masyarakatnya. Kebutuhan-kebutuhan tersebut menjalin membentuk sistem-budaya yang mencerminkan manusia sebagai makhluk biologis, sosial-psikologis dan spiritual yang berpikir dan bercita-rasa (Sachari,2002)

Melalui mainan dan permainan, aktivitas kehidupan manusia diperkenalkan melalui seluruh kemampuan dasar dari tubuh; antara lain melempar, menendang, mendengar, memukul dan sejenisnya. Aktivitas kehidupan seperti itu menjadi media pengetahuan fungsi tubuh. Interaksi manusia dengan wujud alam dilakukan pada masa kanak-kanak melalui bermain, salah satu contohnya adalah saat anak bermain dengan angin, interaksi anak dengan angin kemudian tercipta mainan kolécér (baling-baling). Dalam konteks ini, mainan (baling-baling) telah menjadi media komunikasi anak dengan angin yang tidak terlihat namun kemudian dapat dikenali sifatnya.

Permainan Sunda telah dapat ditemukan Sejak abad ke 14 masehi, catatan lokal mengenai mainan yaitu terdapat dalam naskah Siksa Kanda Ng Karesian yang berasal dari Kabuyutan Ciburuy yang berada di lereng gunung Cikuray Garut Selatan. Dalam naskah tersebut, ditemukan bahwa seorang yang mempunyai keahlian dalam permainan disejajarkan dengan keahlian lain seperti ahli pantun, ahli karawitan, ahli cerita atau dalang, ahli tempa, ahli ukir, ahli masak, dan ahli kain. Keahlian lainnya dalam naskah Siksa Kanda Ng Karesian disebutkan:

“.... Hayang nyaho di pamaceuh ma: ceta maceuh, ceta nirus, tatapukan, babarongan, babakutrakan, ubang-ubangan, neureuy panca, munikeun le(m)bur, ngadu lesung, asup kana lantar, ngadu nini; singsawatek (ka) ulinan ma, hempul Tanya...." ( "....Bila ingin tahu permainan, seperti: ceta maceuh, ceta nirus, tatapukan, babarongan, babakutrakan, ubangubangan, neureuy panca, munikeun le(m)bur, ngadu lesung, asup kana lantar, ngadu nini: segala macam permainan, tanyalah empul"), (Saleh Danasamita,1986: 83, 107).

Di dalam Naskah Siksa Kanda $\mathrm{Ng}$ Karesian disebutkan ada 11 jenis permainan yang ada pada masa itu. Permainan tersebut yaitu : Ceta maceuh, Ceta nirus, Tatapukan, Babarongan, Babakutrakan, Ubang-ubangan, Neureuy Panca, Munikeun Lembur, Ngadu lesung, Asup kan lantar, Ngadu nini. Bentuk mainan dan permainan tersebut berbeda dengan mainan dan permainan yang ada di wilayah Sunda pada umumnya, beberapa permainan itu memiliki kemiripan dengan mainan tradisional di wilayah masyarakat adat di wilayah Sunda, salah satu wilayah yang mempertahannkan budaya Sunda melalui kearifan yang dimilikinya, yaitu masyarakat Baduy-Dalam di Wilayah Banten.

Kehidupan Masyarakat Baduy yang menjaga nilai-nilai tradisinya dari pengaruh dunia luar menjadikan kehidupan anak-anak di Masyarakat Baduy berbeda dengan masyarakat Sunda pada umumnya. Mereka memiliki sistem dan pola asuh dalam mainan dan permainnnya sendiri, menurut para ahli dalam Perkembangan seorang anak tidak terpisahkan dari aktivitas sosial budayanya. Di masyarakat Baduy-Dalam menurut Puun (Pimpinan adat tertinggi di Baduy Dalam) bermain bukan merupakan bagian dari kehidupan- 
nya, mereka tidak mengenal istilah bermain atau ulin dalam bahasa Sunda, sebagai bagian dari sistem pola asuh anak (Wawancara, Jaro Adata Cibeo, Jar Sami, 2013). Kegiatan anak-anak dalam pola asuh masa kanak-kanaknya di masyarakat Bauy dikenal mereka dengan sebutan "Pagawéan Barudak". Istilah pagawéan merujuk pada hasil yang dilakukan oleh anak-anak Baduy. Pagawéan barudak yang dilakukan oleh anak-anak di Baduy-Dalam adalah kegiatan atau pola yang membangun sistem pengetahuan dan pembelajaran budaya dan aturan, yang termuat dalam pikukuh atau aturan hidup masyarakat Baduy dan di sampaikan melalui proses kegiatan pagawéan barudak.

\section{METODE}

Tulisan ini merupakan hasil penelitian kualitatif dengan pendekatan Estetika Formal (Formal Aesthetic Explanation) yang bertujuan untuk melihat bentuk dan makna keindahan yang terwujud melalui simbolsimbol bentuk pagawean barudak masyarakat Baduy-Dalam. Uraian latar perwujudan pagaweanbarudakdianalisa secara mendalam melalui perspektif budaya masyarakatnya (Cultural Explanation).

Pada penelitian ini dilakukan penginvestigasian budaya (investigatingculture) melalui studi mendalam (in-depth study) di masyarakat Baduy-Dalam di wilayah tangtu yaitu wilayah kampung Cibeo, Cikeusik dan Cikartawana, dan peneltian ini berfokus pada pagawéan barudak yang berupa aktivitas dengan tubuhnya. Metoda penelitian ini menggunakan metoda etnografi yang dengan pendekatan cognitive anthropology, atau etnorafi baru atau etnoscience dengan memusatkan penelitian pada kegiatan anakanak di masyarakat Baduy-Dalam. Adapun langkah oprasional etnografi ini menggunakan lima prinsip, yaitu teknik tunggal, identifikasi tugas, maju bertahap. Langkahlangkah yang dilakukan dalam penggunaan metoda etnografi Penelitian Maju Bertahap (The Developmental Research Sequence) dengani ciri mendefinisikan budaya sebagai sistem pengetahuan yang diperoleh manusia melalui pengamatan proses belajar. Langkah-langkah yang digunakan pada penelitian ini adalah menggunakan teknik penelitian tunggal, seperti teknik wawancara etnografik yaitu informan yang merupakan pelaku atau tokoh di masyarakat adat Baduy-Dalam, Puun, Jaro, dan pelaku mainan dan permainan (pagawéanbarudak). Melakukan identifikasi tugas/langkahlangkah yang harus dilakukan, menyusun strategi atau tahapan dan menyelaraskan dengan aturan adat yang ada di masyarakat Baduy-Dalam. Setiap langkah dilakukan secara berurutan atau maju bertahap, melakukan wawancara etnografik yang dilakukan benar-benar di lapangan, di lakukan langsung di Baduy-Dalam.

\section{PEMBAHASAN DAN HASIL}

Seperti diungkapkan oleh Kristian Bjornard bahwa desain vernakular memiliki Konsep, keterbatasan, daya tahan, dan penghematan menjadi model evolusi vernakular. Prinsip yang sama diterapkan dalam praktek desain modern untuk mendapatkan cara-cara baru.

Apa yang membuat budaya umum begitu istimewa adalah yang memiliki kemampuan untuk bertahan dan berkembang terus dari waktu ke waktu, sebagai pelaku desain dalam konteks budaya bisa menggunakan pola-pola umumnya tersebut dengan konsep kendala, daya tahan dan hemat. Menurut Victor Papanek (1992) mengemukakan enam paparan (six explanations): pertama, Paparan Metodologis (Methodological Explanation), bahwa desain vernakular dapat dilihat dari metodenya 
yang merupakan gabungan dari material, alat dan proses; kedua, Paparan Dispersi dan Konvergensi (Dispersion and Convergence Explanation). Dispersi menunjuk pada penyebaran suatu gaya desain dari suatu wilayah ke wilayah lain mengalami perubahan dalam upaya adaptasi dengan kondisi lingkungan baru; ketiga, Paparan Evolusi (Evolusionary Explanation), yaitu bahwa meskipun desain vernakular berakar pada nilai-nilai tradisional, menyimbolkan kontinuitas di dalam masyarakan yang pada bagian tertentu tampak adanya sejumlah perubahan meskipun cenderung lamban; keempat, Paparan Lingkungan Sosial (SocialEnviromental Explanation) yaitu bahwa vernakular mencerminkan kebutuhan masyarakat dan kemasyarakatan (social and societal needs), lahir dari kebutuhan masyarakat; kelima, Paparan Budaya (Cultural Explanation) yaitu dipengaruhi oleh budaya masyarakat setempat terutama dalam tata cara, dan adat istiadatnya; dan keenam, Paparan Estetika Formal (Formal Aesthetic Explanation) yaitu bahwa estetika desain vernakular/tradisional berbeda dengan desain yang menonjolkan nilai

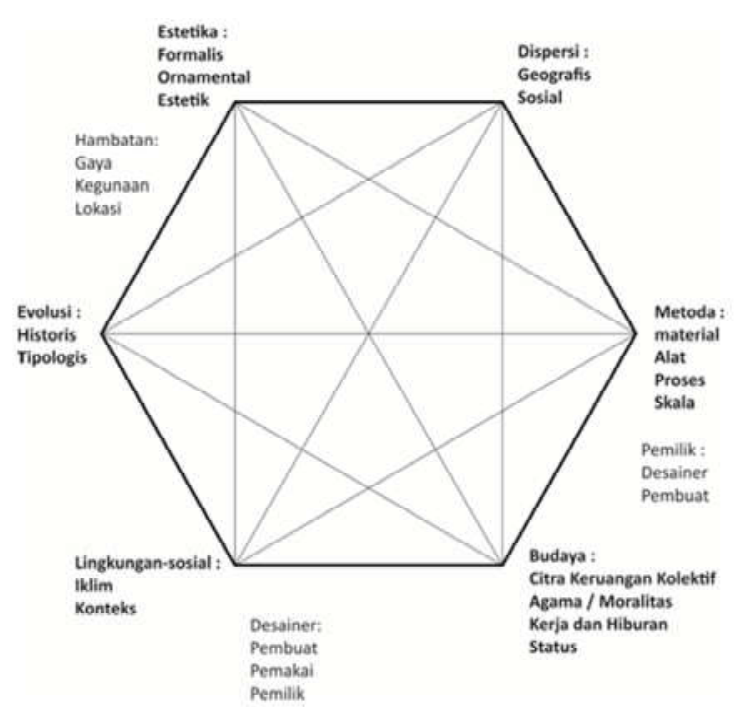

Gambar 1.

Jaring Dinamis

(Dynamic Web by Victor papane) artistik individualistik yang dipandang sebagai sebuah ungkapan cita rasa.

Dalam konteks ini desain vernakular tidak muncul sebagai sebuah pernyataan, tetapi lebih mengedepankan unsur simbolik dibanding unsur fisik. Tinjauan terhadap desain tradisional pada tulisan ini diawali dari pemahaman-pemahaman terhadap latar budaya kemunculan desain itu sendiri. Seperti disampaikan oleh Victor Papanek (1992) bahwa cara pandang masyarakat modern dengan budaya ontologis berbeda dengan masyarakat budaya mitis, pola ini yang disebut dengan jaring dinamis ( $D y$ namic Web) :

Matriks vernakular di atas akan dijadikan acuan pada penelaahan bentuk-bentuk desain tradisional pagawean barudak. Matrik vernakular merupakan gabungan dari berbagai unsur dan setiap unsur saling terkait satu sama lain. Pada matrix vernakular di atas dapat diketahui unsurunsur yang berpengaruh pada desain tradisional yaitu : Metode, (material, alat, proses dan skala); Budaya (citra ruang kolektif, agama-moralitas, kerja-hiburan, dan status); Desainer (pembuat, pemakai, pemilik); Lingkungan-sosial (iklim, konteks); Evolusi (historis, tipologi) dan Estetika (formalis, ornamental, organik). Posisi atau kedudukan masing-masing unsur tersebut di dalam suatu proses penciptaan desain tradisonal bersifat khas. Misalnya unsur Desainer, di masyarakat tradisional sekaligus adalah pembuat, pemakai, dan pemilik, sedang unsur Evolusi menunjuk pada perubahan bentuk secara evolusioner baik secara tipologis maupun historis. Tipologis menunjuk pada adanya perbedaan tertentu tetapi dengan tipe bentuk yang sama, sedang unsur Historis menunjuk pada faktor sejarah perkembangan desain tersebut. Unsur Dispersi yang terdiri dari dua faktor yaitu geografis dan 
sosial menunjuk pada sifat desain tradisional yang menyebar dalam wilayah dalam batas geografis dan lingkungan sosial tertentu.

Unsur Estetik yang mencakup faktor bentuk (formalis), ornamentasi dan organik menunjuk adanya acuan baku yang dimiliki masyarakat pencipta desain tersebut dalam hal bentuk, jenis ornamentasi dan karakteristik organik. Pengertian organik kemungkinan mengacu pada bentuk yang bersumber pada karak-teristik serta bahan atau material alami. Seluruh unsur tersebut merupakan warisan dari generasi sebelumnya yang ditiru generasi berikut tanpa perubahan yang berarti sebagaimana karakteristik umum desain tradisional.

\section{Pemahaman arti dan makna Mainan dan permainan masyarakat Baduy-Dalam}

Kampung Girang, sebutan masyarakat Baduy-Luar terhadap Baduy-Dalam Cibeo, Cikeusik, Cikartawana, dipimpin oleh seorang Puun yang pada wawancara kami dengan Jaro wakil Puun Jaro Sami menyebutkan bahwa kegiatan bermain tidak dikenal di Baduy-Dalam. Puun sebagai pimpinan adat, agama dan menguasai wilayah yang tak terbatas (Judistira K. Garna 1987)

“ jenis nu disebut kaulinan barudak di dayeuh, anu sifatna heureuy nu senangsenang, di kami mah euweuh, jeung dilarang ku adat. euweuh kaulinan da lain tugas kami keur ulin"

"Jenis yang disebut permainan anak-anak di kota, yang memiliki sifat bermain-main dan bersenang-senang, di masyarakat kami tidak ada, serta dilarang oleh adat, tidak ada permainan karena tugas kami bukan untuk bermain"

(Wawancara Jaro adat Cibeo, Jaro Sami 2013)

Istilah ulin atau bermain bukan merupakan tugas masyarakat Baduy, di dunia mereka menghindari kesenangan. Baduy dituntut hidup sederhana dengan mengutamakan barang-barang buatan sendiri. Gunggung Senoaji (2011) menyebutkan mainan dan permainan dianggap sesuatu yang main-main atau melakukan pekerjaan tanpa tujuan dan tidak berguna, hanya bersenang-senang. Kata tersebut tidak dikenal di wilayah Baduy-Dalam karena berarti heureuy, atau kaheureuyan, akan tetapidi wilayah tersebut sangat dilarang melakukan kegiatan-kegiatan yang tidak berguna atau tidak bermanfaat.

“....cara hidup orang Baduy selalu mengikuti aturan dan larangan, karena rasa takut yang besar, mereka menghindari segala hal yang dapat membangkitkan kegembiraan dan kemanjaan hidup.

(J.J Meijer 1891).

\section{Bentuk Pagawéan Barudak Baduy-Dalam}

Penentu desain dalam masyarakat "primitif" (tradisional, vernakular) adalah lingkungan yang kita urai melalui konsep desain vernakular dapat dilihat dari metodenya yang merupakan gabungan dari material, alat dan proses. Material pada bentuk Pagawéan Barudakdi kaji melalui teori vernakular desain, hal ini dilakukan untuk mengurai bentuk pagawean barudak dari material, dispersi atau penyebarnnya yang akandilihat dari aspek geografis dan sosialnya, serta penyebaran desain ke wilayah sekitarnya. Dalam Evolusi (Evolusionary Explanation), yaitu berhubungan dengan kontinuitas desain di masyarakat yang menunjukan perubahan. Bentuk yang dilahirkan dari kebutuhan masyarakat di urai melalui paparan lingkungan sosial (social and societal needs).

\section{Kancung}

Kancung adalah sebuah kegiatan pagawéan barudak dengan menggunakan 


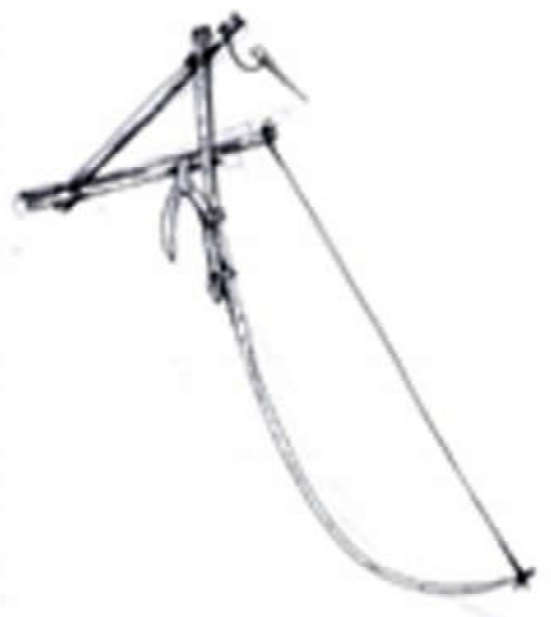

Gambar 2.

Bentuk Kancung, pagawéan barudak di Baduy Dalam

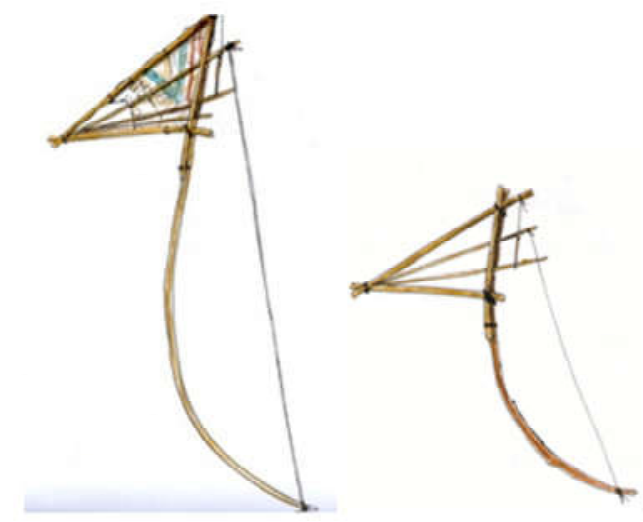

Gambar 3

Kancung baduy luar dan kancung Baduy Dalam alat yang bertujuan menangkap burung di dahan, cara memasang kancung yang dikaitkan pada pohon untuk menangkap binatang seperti burung-burung kecil. Bentuk kancung seperti bentuk jerat yang menangkap burung dengan jepitan yang dihasilkan dari elastisitas bahan yang digunakannya. Kancung Manuk (burung) yang digantungkan di dahan pohon.

Material yang digunakan untuk membuat kancung terdiri dari bambu tali (Gigantochloa apus), Tali menggunakan beberapa tanaman, yaitu kulit pohon teureup (Artocarpus elasticus), Tanaman kasungka (Gnetum neglactum). Pada bentuk utamayang menggunakan dahan pohon ada kebebasan yang boleh dilakukan dengan syarat, menggunakan material alam yang memiliki sifat elastis mereka menggunakan bambu tali (Gigantochloa apus), tetapi banyak pula yang menggunakan ranting pohon yang memiliki elastisitas tinggi.

Paparan Dispersi dan Konvergensi (Dispersion and Convergence Explanation), bentuk kancung menunjukan bahwa, sebaran dari Pagawéan barudak ini menyebar sama di tiap kampung yang ada di Baduy-

Tabel 1. paparan vernakular desain pagawéan barudak kancung

\begin{tabular}{|c|c|c|c|c|c|c|c|}
\hline Bentuk & Material & skill & Dispersi & evolusi & kebutuhan & cultural & Simbol \\
\hline & $\begin{array}{c}\text { Bambu Tali } \\
\text { (Gigartochloa } \\
\text { apus) }\end{array}$ & $\begin{array}{c}\text { Mengenal jenis } \\
\text { pohon }\end{array}$ & $\begin{array}{l}\text { Di wilayah } \\
\text { Baduy } \\
\text { Dalam dan } \\
\text { Baduy } \\
\text { Luar }\end{array}$ & $\begin{array}{c}\text { Penggunaan } \\
\text { material di } \\
\text { baduy luar } \\
\text { yang } \\
\text { menggunakan } \\
\text { material } \\
\text { modem. }\end{array}$ & $\begin{array}{c}\text { Makanan } \\
\text { Kegiatan } \\
\text { seorang anak }\end{array}$ & $\begin{array}{c}\text { Budaya } \\
\text { berburu dan } \\
\text { beriadang }\end{array}$ & $\begin{array}{c}\text { Cerita } \\
\text { budak } \\
\text { buncireong } \\
\text { dan } \\
\text { daleom } \\
\text { sangkan }\end{array}$ \\
\hline & $\begin{array}{c}\text { Pohon Teureap } \\
\text { (Artocappus } \\
\text { elasticus) }\end{array}$ & $\begin{array}{c}\text { Material } \\
\text { Mambuat tali } \\
\text { Tali-temali }\end{array}$ & & & & & \\
\hline & $\begin{array}{c}\text { Tanaman } \\
\text { kasungka } \\
\text { (Gretum } \\
\text { neglactum) }\end{array}$ & $\begin{array}{l}\text { Membentuk } \\
\text { Keseimbangan }\end{array}$ & & & & & \\
\hline
\end{tabular}


Dalam yaitu, Cibeo, Cikeusik dan Cikertawana.Pergeseran material yaitu penggunaan karet, dan tali yang menggunakan materal plastik serta bagin kepalanya sering di tempelkan gambar-gambar dengan warna-warna. Perbadingan antara kancung Baduy-Luar dengan kancungBaduy-Dalam:

Dari paparan lingkungan sosial (SocialEnviromental Explanation) bentuk kancung merupakan akibat dari kebutuhan masyarakat Baduy dari kebutuhan kegiatan anakanak sampai kebutuhan untuk pemenuhan kebutuhan pokok, kancung terbentuk karena interaksi manusia Baduy dengan alam dan lingkungnnya yang diatur oleh aturan, yang merupakan konsep scaffolding dari pemikiran Vygotsky yaitu konsep level dukungan dan instruksi langsung dengan perintah, atau pikukuh di masyarakat Baduy. Dari kebutuhan tersebut lahirlah media untuk melakukannya, yaitu alat yang menggunakan bahan-bahan dan material yang sudah ditentukan adat, yang termasukPaparan Budaya Cultural Explanation dalam desain vernakular.

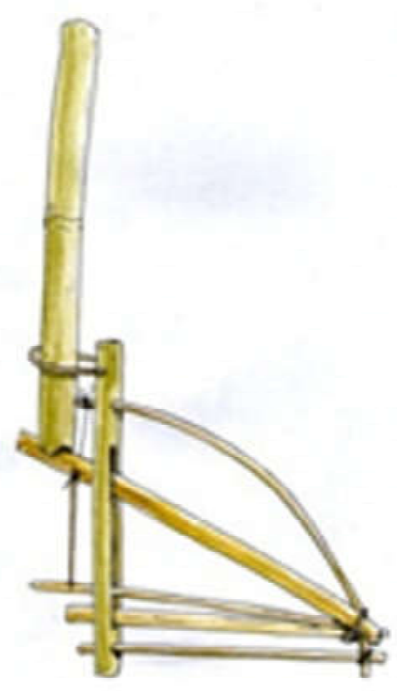

Gambar 4. Bentuk Pitondok
Kancung merupakan bentuk dan simbol dari cerita yang disampaikan oleh leluhurnya melalui cerita-cerita yaitu carita Budak Buncireung, yang menggambarkan simbol dari menangkap burung. Pada bentuk kancung gedé pola yang terjadi hampir sama dengan kancung manuk tetapi beberapa material yang digunakan ada yang berbeda meskipun sistem yang digunakan sama.

Hasil yang ingin di dapatkan adalah binatang yang lebih besar, yang berbeda dengan kancung manuk hanya menangkap burung. Hal ini menunjukan pola yang sama yang dimiliki oleh bentuk kancung manuk dan kancung gedé tetapi berbeda pada saat digunakan karena kancung gedé dipasang di atas tanah.

\section{Pitondok}

Bentuk pagawéan barudakBaduy-Dalam Pitondok memiliki kesamaan bentuk dengan kancung manuk dan kancung gedé tetapi pemasangannya terbalik yang membentuk seperti kepala binatang dan tidak membentuk seperti paruh burung halnya pada bentuk kancung manuk. Pitondok dipasang-kan dengan cara digantung di atas pohon pada bagian dahan yang besar. Pembuatan dengan menggunakan bahan-bahan dan material alam seperti bambu yang menjadi material utamanya dan berbagai macam jenis tanaman yang digunakan untuk tali dan bagian bentuk lainnya. Dengan memanfaatkan gaya gravitasi dari berat bambu atau kayu maka hewan akan tertangkap.

Bentuk pitondok yang digantungkan dan tidak menempel pada tanah menunjukan pada apa yang akan ditangkapnya, yaitu binatang yang memang berada di ketinggian. Proses dan konsep dalam bentuk pitondok pun menunjukan pada apa yang sudah menjadi garis-garis ketentuan leluhur dan dijalankan sesuai dengan pikukuh Baduy. 
Material untuk membuat pitondok adalah bambu dan tanaman kasungka (Gnetum neglactum) yang merupakan material untuk digunakan sebagai tali pada bagian-bagian pitondok. Bentuk pitondok ada di tiga wilayah di Baduy-Dalam, mereka menangkap binatang, memakai alat dengan desain dan bentuk yang sama. Pitondok di wilayah Baduy-Luar memiliki bentuk yang menyerupai, tepapi dengan material yang berbeda.

Dari sisi paparan estetika formal bentuk dan desain pitondok adalah bentuk yang memiliki simbol kesadaran dan tujuan yang ingin dicapai (jenis binatang yang akan ditangkapnya dan material yang digunakannya) adalah simbol kepatuhan masyarakat terhadap adat dan pikukuh yang diyakininya. Mereka melakukan praktik ritual dengan berpedoman pada pikukuh, aturan adat, dan ketaatan kepada buyut, pantangan. Keimanan seperti itu merupakan semangat untuk menjaga hutan, sungai dan gunung hidup harmoni (Masykur Wahid, 2010).

\section{Pikeplok atau Pikepluk}

Bentuk pagawéan barudakBaduy-Dalam dengan bentuk pikeplok, berasal dari suara yang berbunyi "plok", analisa ini berasal dari perbandingan dengan bentukpikepuk. Bentuk pikepuk, lebih besar menghasilkan suara keras "pluk" dengan material memakai ruasan bambu yang besar, dengan fungsi yang berbeda.

Bentuk pikeplok yang menghasilkan suara berasal dari bertemunya kedua bilah bambu yang bertemu tiba-tiba. Pikeplok dengan ukuran yang lebih kecil berfungsi untuk mengagetkan orang lewat atau menandai ada orang yang lewat dan dipasang di sekitar kampung atau sekitar saung ladang.

Pikeplok memakai bambu yang dibelah, dengan bagian yang direnggangkan dan bagian yang dibuat lebih besar untuk menghasilkan suara yang lebih keras pula. Pertemuan kedua bilah tersebut karena talinya lepas karena terkait saat kaki melewati wilayah itu. Pada pikepluk, suara yang dihasilkan dari jatuhnya bambu mengenai tanah dan mengagetkan hewan buruan sehingga berlari ke arah lain atau kearah yang diharapkan. Arah yang diharapkan yang menjadi jalan binatang berlari adalah arah yang sudah dipasangi burang atau daerah yang dipenuhi oleh bambu-bambu yang runcing yang dapat menangkap hewan buruan jika berlari kencang sehingga menusuk burang yang kita siapkan.

Material yang terbuat dari bambu dengan menggunakan talilolo(Epipremnum pinnatum 'aureum') dibuat oleh masyarakat

Tabel 2. paparan vernakular desain pagawéan barudak pitondok

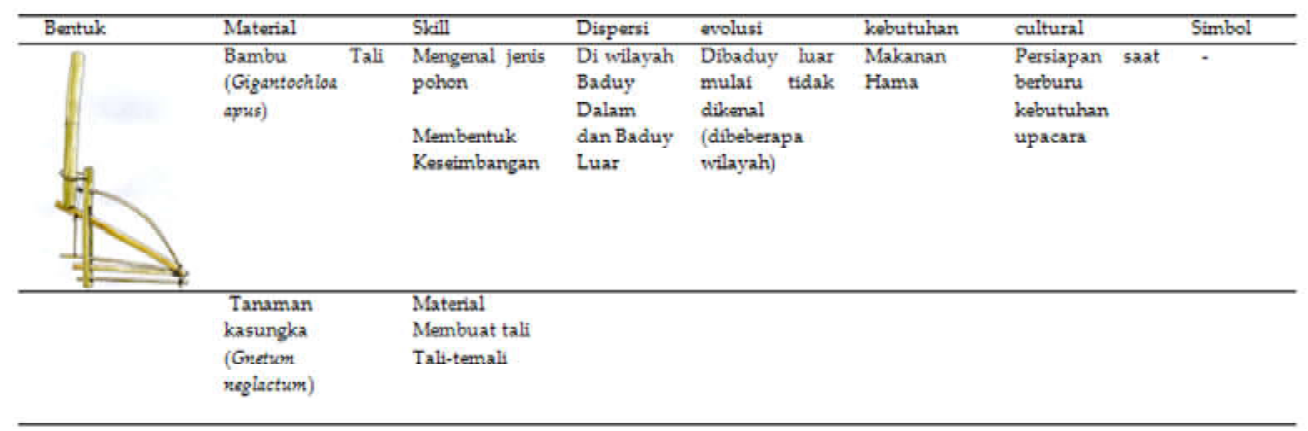




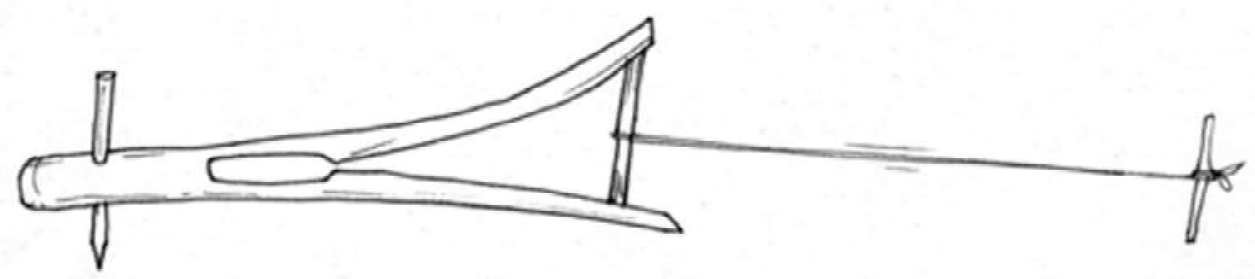

Gambar 5.

Bentuk pikeplok dengan tali yang bisa dipanjangkan sesuai wilayah yang dilewatinya.

dengan teknik yang sangat sederhana, yaitu dengan caramembelah bambu dan membuat lubang di ujung belahan bambu tersebut agar gerakannya lebih fleksibel. Ukuran yang digunakan disesuaikan dengan suaran yang ingin dihasilkan, tetapi rata-rata mereka membuat dengan ukuran 1-2 jeujeuh, yaitu ukuran sepanjang telapak kaki orang yang membuatnya. Hal ini terjadi karena pikeplok harus tersembunyi agar tidak bisa terlihat oleh target yang akan melewatinya.

Perubahan fungsi pada pikeplok di masyarakat Baduy-Luar yaitu terjadi ketika pikeplok digunakan bukan sebagai pagawéan barudak untuk mengusir binatang yang mengganggu tanamannya, tetapi pikeplok digunakan untuk fungsi yang berbeda yaitu dengan fungsi untuk mengagetkan orang lain atau temannya yang melewati wilayah tersebut. Hal tersebut tidak terjadi di wilayah Baduy-Dalam karena merupakan hal yang ditabukan dan sangat dilarang. Hal ini terjadi diduga karena jarangnya binatang yang melewati wilayah BaduyLuar. Penggunaan pikeplok berkaitan dengan aturan-aturan di masyarakat Baduy yang masih mengharuskan masyarakat menanam padi di ladang. Letak ladang yang sangat jauh dari keramaian kampung, menyebabkan pikeplok dibuat oleh masyarakat sebagai penjaga tanamannya. Benda ini dibuat oleh anak-anak sebagai pekerjaan dengan tujuan membantu orangtuanya. Bentuk yang dihasilkan dari pikepluk adalah bentuk yang sangat mudah dicapai oleh material yang digunakannya. Sangat sederhana dengan fungsi yang sangat bermanfaat. Bentuk-bentuk yang menyerupai pikeplukpun banyak ditemui di beberapa produk yang dipakai oleh masyarakat Baduy Dalam.

\section{Turub Sumbul}

Turub sumbul adalah bagian penutup dari perkakas berupa sumbul yaitu sebuah wadah yang digunakan masyarakat Baduy untuk berbagai keperluan. Sumbul merupakan wadah yang memiliki fungsi yang panjang dari masa kecil atau masa pupulih, masa anak-anak atau masa pagawéan barudak, masa nikah atau masa mantera ataujampi hinggamasa tua atau masa pagawéan kolot. Dalam tiap tahapannya sumbul mempunyai peranannya.

Sumbul terbuat dari bahan bambu yang membentuk menyerupai boboko atau wadah nasi di masyarakat Sunda pada umumnya tetapi dengan ukuran kecil serta memanjang. Sumbul terbuat dari bahan utama 
Tabel 3. paparan vernakular desain pagawéan barudak pikeplok/pikepluk

\begin{tabular}{|c|c|c|c|c|c|c|c|c|}
\hline Bentuk & & Material & skill & Dispersi & evolusi & kebutuhan & cultural & Simbol \\
\hline & $F$ & $\begin{array}{c}\text { tali lolo } \\
\text { (Epipremnum } \\
\text { pinnatum } \\
\text { 'aureum') } \\
\begin{array}{c}\text { Bambu Tali } \\
\text { (Gigantochloa } \\
\text { apus) }\end{array}\end{array}$ & $\begin{array}{c}\text { Mengenal jenis } \\
\text { pohon } \\
\text { Mengenal } \\
\text { Binatang } \\
\text { Menjaga } \\
\text { tanaman } \\
\text { Membentuk }\end{array}$ & $\begin{array}{c}\text { Di } \\
\text { wilayah } \\
\text { Baduy } \\
\text { Dalam } \\
\text { dan Luar }\end{array}$ & $\begin{array}{l}\text { Di Baduy } \\
\text { Luar } \\
\text { sudah } \\
\text { menjadi } \\
\text { mainan } \\
\text { untuk } \\
\text { mengagetk } \\
\text { an }\end{array}$ & $\begin{array}{l}\text { Menjaga } \\
\text { tanaman }\end{array}$ & $\begin{array}{c}\text { Persiapan saat } \\
\text { berburu } \\
\text { kebutuhan } \\
\text { upacara }\end{array}$ & \\
\hline & & & $\begin{array}{l}\text { Membuat tali } \\
\text { Tali-temali }\end{array}$ & & & & & \\
\hline
\end{tabular}

perkakas atau alat di masyarakat Baduy yaitu bambu. Karena penggunaan yang ada ditiap tahapan usia masyarakat Baduy maka banyak sumbul yang berwarna hitam kemerahan, hal ini terjadi karena sumbul disimpan diatas parako atau perapian di masyarakat Baduy dan diolesi sejenis getah dari pohon berwarna merah tua agar awet dan tahan cuaca.

Turub sumbul seperti yang diungkapkan oleh J.J Meiyer (1891) merupakan sebuah permainan atau pagawéan barudak dengan menggunakan tutup dari sumbul tersebut. Sumbul merupakan bagian dari pagawéan barudak tersebut yang membagi dua dengan dua fungsi yang berbeda. Sumbul digunakan pada masa pupulih sebagai media membantu orangtua

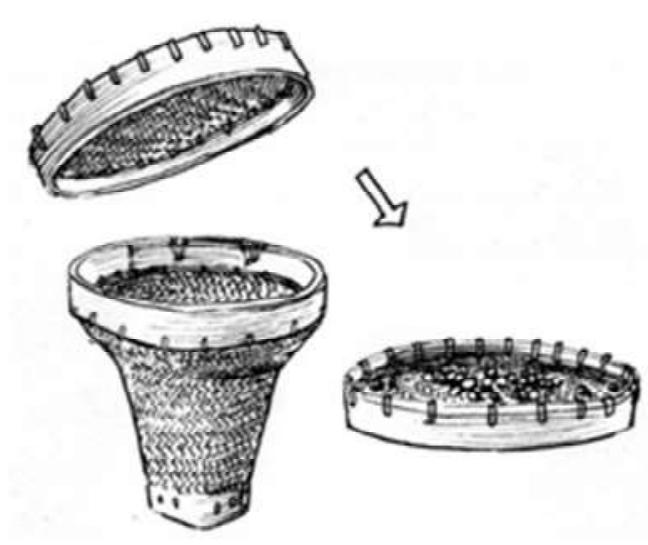

Gambar 6.

Sumbul dengan tutupnya atau turub sumbul. menebarkan biji-bijian pada saat menanan di ladang, dan diawali dengan tahapan pengajarannya melalui turub sumbul. Keinginan anak untuk mengikuti kegiatan orangtuanya memakai sumbul diikuti anak dengan menggunakan turub sumbul.

Turup sumbul memiliki peran penting pada pengajaran dan alih pengetahuan berladang pada seorang anak. Turub sumbul dinamakan "tetapi" di wilayah Baduy. Turup sumbul adalah sebuah benda dengan fungsi yang sama tetapi pemakaian yang berbeda. Sumbul tersebar di hampir seluruh wilayah Baduy-Luar dan Baduy Dalam, karena memiki fungsi yang beragam dari tahapan masa kecil sampai masa dewasanya. Hal ini berkaitan dengan jenis-jenis upacara yang harus dilaluinya dengan menggunakan sumbul. Penyebaran sumbul ke wilayah-wilayah Baduy sampai ke Baduy-Luar melalui berbagai kegiatan upacara yang sama di tiap wilayah yang di satukan dalam satu kegiatan, seperti séba, kawalu. Sumbul merupakan pagawéanbarudak anak-anak perempuan setelah melewati masa pupulih.

Sumbul hadir merupakan kebutuhan masyarakat atau kemasyarakatan yang hadir baik sebagai wadah dengan fungsi yang berbeda-beda atau sebagai media pembelajaran (experiental learning) yaitu metoda pembelajaran langsung dari seorang orang tua Baduy untuk ketu- 
runannya. Sumbul dibuat sendiri oleh orang tuanya dan diberikan kepada anak perempuannya ketika masa pupulih akhir, menuju masa pagawéan barudak. Beberapa sumbul di wilayah Baduy-Dalam tidak dilengkapi tutup atau turub. Hal ini dikarenakan turubsumbul atau tutup sumbul digunakan berbeda fungsinya dengan sumbul itu sendiri. Tutupnya sering dipakai anak-anak perempuan melakukan peniruan terhadap kegiatan napi (proses memisahkan beras dengan gabah). Tutup sumbul sering digunakan anak-anak untuk meniru proses napi tersebut. Sehingga kecenderungannya sumbul di wilayah tertentu tidak ada tutupnya.

Pada masa tua, sumbul kemudian berubah fungsi lagi sebagai tempat menyediakan kebutuhan pasangannya apabila meninggal dunia. Bentuknya merupakan simbol-simbol dari perempuan sebagai wadah di dalam keluarganya.

\section{Calintu atau Sonari}

Calintu atau Sanarimerupakan pagawéan barudak yang menghasilkan suara, yaitu sebatang atau lebih bambu-bambu yang diberi lubang persegi di ruasnya. Pada lubang tersebut ketika angin meniupnya akan menghasilkan suara seperti siulan tetapi dengan banyak sumber suara.
Calintu dibuat dengan metoda yang sangat sederhana yaitu menggunakan pengukuran dengan cara Baduy. Jarak yang digunakan untuk lubung yaitu sajeungkal bambu di awal ruas bambunya, kemudian makin keras lubang tersebut dikurangi dengan menggunakan potongan bambu. Tahapan demi tahapan bambu dilubangi dengan ukuran bambu kecil tadi pada saat berpindah ruas potongan bambu tersebut dikurangi saramo-saramo sampai ke ujung atas kayu.

Ukuran calintu bervariasi tergantung ukuran bambu yang dibutuhkan, serta mempertimbangkan suara yang ingin dihasilkan. Semakin besar dan tinggi ukuran calintu maka suara yang dihasilkan akan semakin keras. Di Baduy-Dalam, keras dan lembutnya suara tidak menentukan keberhasilan pembuatan calintu, melainkan jika suara yang dihasilkan terus menerus tanpa henti maka calintu dinyatakan berhasil atau bagus. Oleh sebab itu, banyak sekali calintu ditempatkan di ladang-ladang yang berada di ketinggian. Suara yang dihasilkan terus menerus adalah simbol dari keyakinan masyarakat Baduy tentang pengabdian pada Hyang Sri atau Dewi Padi melalui suara yang dihasilkan dari calintu.

Penyebaran calintu tersebar di seluruh wilayah Baduy-Dalam sampai ke Baduy-

Tabel 4.Paparan vernakular desain pagawéan barudak turub sumbul

\begin{tabular}{|c|c|c|c|c|c|c|c|}
\hline Bentuk & Material & Skill & Dispersi & evolusi & kebutuhan & cultural & Simbol \\
\hline & $\begin{array}{l}\text { Bambu Tali } \\
\text { (Gigantochloa } \\
\text { apus) }\end{array}$ & $\begin{array}{l}\text { Kegiatan } \\
\text { menebar benih, } \\
\text { Napi beras, } \\
\text { menggendong } \\
\text { atau membawa } \\
\text { barang }\end{array}$ & $\begin{array}{l}\text { Di } \\
\text { wilayah } \\
\text { Baduy } \\
\text { Dalam }\end{array}$ & $\begin{array}{l}\text { Banyak } \\
\text { yang tak } \\
\text { mengguan } \\
\text { akan turub } \\
\text { atau tutup }\end{array}$ & $\begin{array}{l}\text { Menebar } \\
\text { benih }\end{array}$ & $\begin{array}{l}\text { Budaya } \\
\text { menggendong } \\
\text { dalam } \\
\text { mengasuh } \\
\text { anak }\end{array}$ & $\begin{array}{l}\text { Simbol } \\
\text { anak } \\
\text { yang di } \\
\text { asuhnya. }\end{array}$ \\
\hline & & & & & $\begin{array}{l}\text { Hantaran } \\
\text { ketika } \\
\text { menikah }\end{array}$ & & \\
\hline & & & & & $\begin{array}{c}\text { Wadah } \\
\text { sahalawat di } \\
\text { masa Tua ) }\end{array}$ & & \\
\hline
\end{tabular}




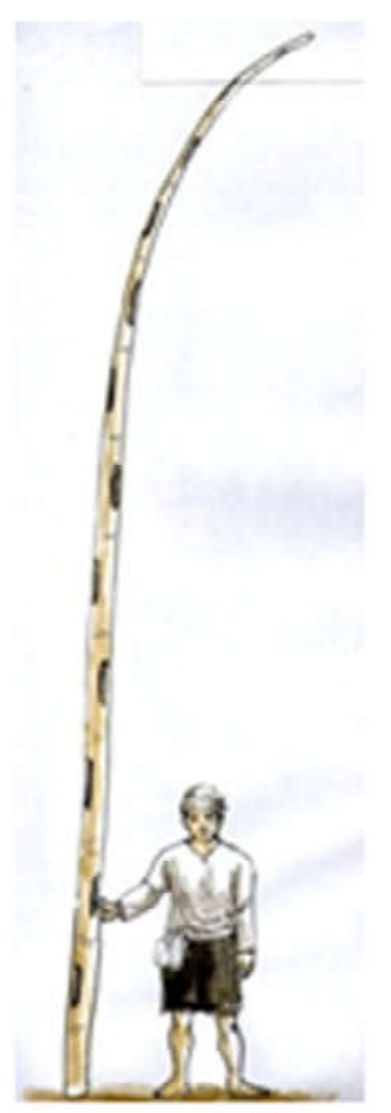

Gamabar 7. Calintu atau sanari

Luar, hampir tidak berubah baik dar bentuk, proses dan materialnya. Calintu atau sanari juga dikenal di masyarakat luar Baduy, tetapi sudah mengalami pergeseran fungsi dan nilai. Di luar Baduy calintu hanya berfungsi sebagai media hiburan masyarakat yang menunggu masa panen tiba. Calintu disimbolkan sebagai bentuk pengabdian terhadap Dewi Sri dan suara yang dihasilkannya diyakini sebagai suara yang sangat disukai oleh Dewi Sri atau Dewi Padi. Suara yang dihasilkannya pun seperti suara dari binatang cacing-cacing sonari, yaitu seekor cacing yang berukuran lebih besar dan panjang dari cacing biasanya dan tersebar banyak di BaduyDalam dan saat sore atau malam hari cacing itu naik ke permukaan lebih tinggi dan mengeluarkan suara yang melengking seperti siulan.

Selain persembahan untuk Hyang Sri juga digunakan oleh masyarakat Baduy sebagai media hiburan saat menjelang panen tiba. Karena saat panen tiba calintu akan digantikan oleh angklung sebagai kebahagiaan masyarakat saat panen tiba. Calintu disimbolkan sebagai bentuk dari "kehamilan padi" yang membutuhkan hiburan sampai ke masa panen tiba. Sepasang benih padi (sakuren) sakral di sebut pare indung di tanan di tengah (Johan Iskandar,1992)

\section{SIMPULAN}

Pagawean barudak melalui kajian desain vernakular menunjukan sebuah model transmisi melalui bentuk Pagawéan barudak yang berfokus pada pelatihan keterampilan. Sebuah pola yang saling berkaitan antara tahapan yang di miliki masing-masing anak-anak, baik itu skill training, sosialisi dan moral education. Pada tahapan Pagawéan barudak memiliki tiga

Tabel 6. Paparan vernakular desain pagawéan barudak calintu

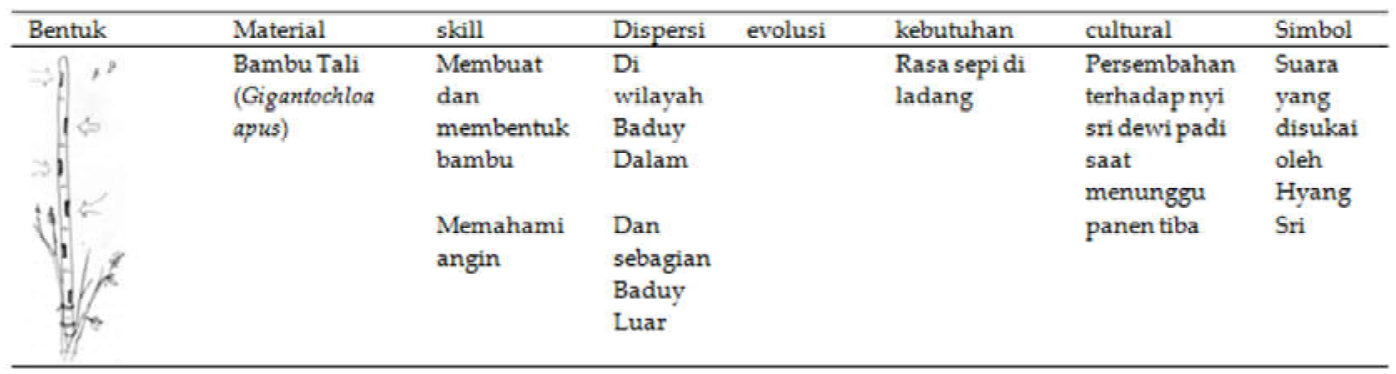


wilayah transmisi yaitu lingkungan yang di dalamnnya, wilayah ladang dan rumah, sehingga bentuk pagawéan barudak yang ada dan berkaitan dengan lingkungan kedua wilayah tersebut, hal tersebut memiliki fungsi seperti menjaga ladang, menebar benih, dan mengusir sepi. Kedua, adalah lingkungan sosial anak dengan beberapa aktivitas seperti berburu, menghibur, mempelajari tali-temali dan memanjat. Lingkungan ketiga, yaitu budaya secara menyeluruh, menyangkut kesadaran hiyang sridan upacara-upacara leluhur.

Pada bentuk pagawean barudak, seperti keteguahan dan kepatuhan di sampaikan melalui keterampilan (skill training) dalam membuat dan menggunakan bentuk-bentuk pagawean barudak, sedangkan kepatuhan disampaikan melalui penggunaan material, bentuk, proses dan hasil dari pagawean barudak. Pelatihan keterampilan yang diberikan melalui modelling orang tuanya yang bertujuan bahwa seorang anak akan menggantikan posisi orang tunya atau mengambil alih peran orang tuanya. Hal tersebut menyebabkan seluruh pagawean barudak menggunakan materai dan fungsi yang sesungguhnya, tidak berbentuk barang yang bukan sesungguhnya. Kemampuan yang dimiliki seorang anak akan disosialisasikan yaitu peran bagaimana seorang anak menggunakan barang-barang dalam pagawean barudak dan menghasilkan. Keberhasilan seorang anak bukan hanya dari keberhasilan menangkap buruannya tetapi dari kepatuhan dan keteguhan dia pada penggunaan dan pemakaian produk tersebut. Adapun nilai-nilai moral dalam pagawean barudak itu disampaikan melalui bentuk benar dan salah dalam pelaksanaan kegiatan pagawean barudak. Seluruh bentuk pagawean barudak mewakili bentuk kepatuhan dan keteguhanyang nampak dan diwujudkan dalam bentuk pelatihan keterampilan dan sosialisasi.

Dalam proses pembuatan produk dalam pagawéan barudak adalah hubungan

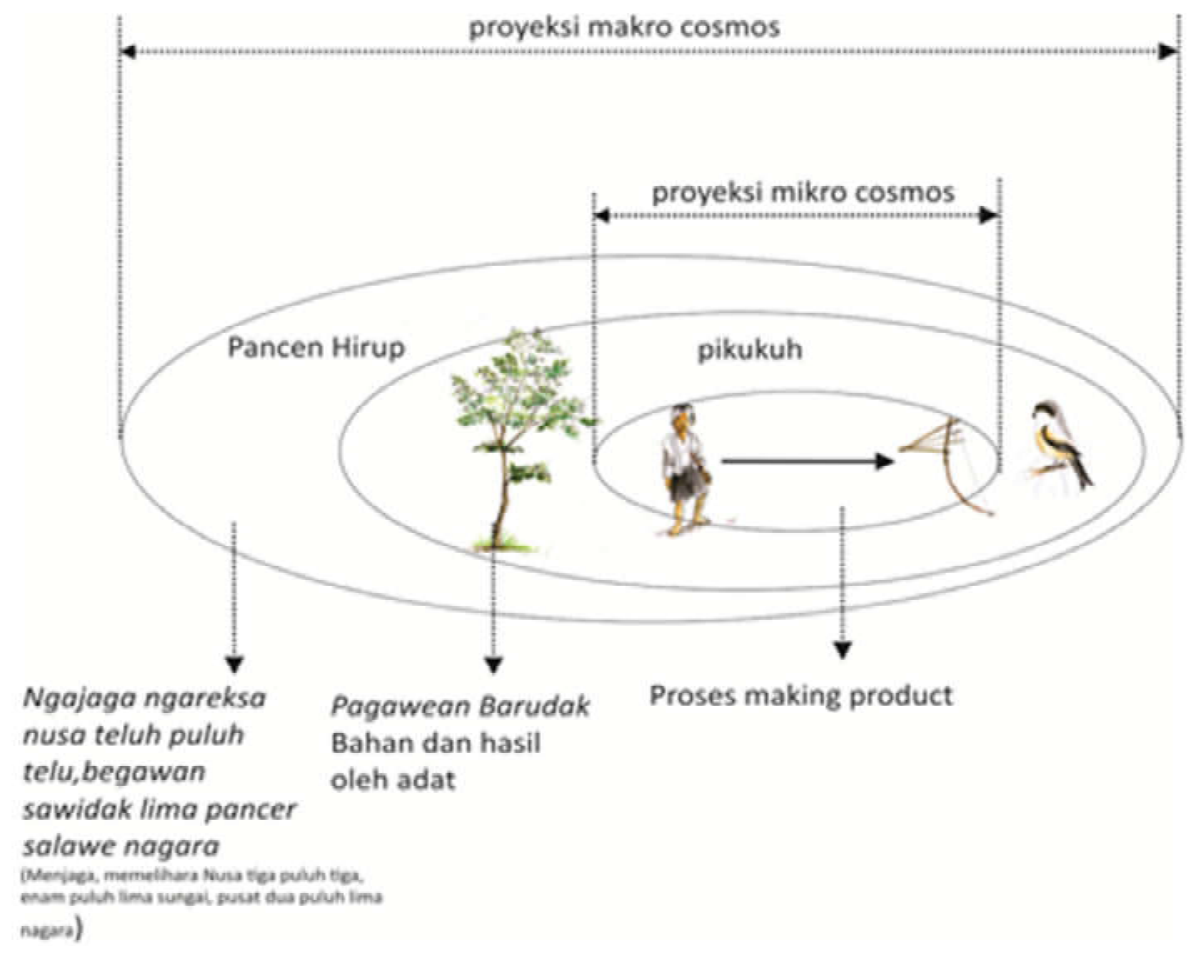


manusia dengan kebutuhan dirinya dengan prinsip memanfaatkan alam lingkungan sekitarnya, kemudian kebutuhan tersebut akan bertemu dengan lingkup aturan adat leluhur yang saling terikat antara diri dan lingkungannya, sehingga lahirlah pikukuh dan pitutur yang harus di taati dalam melakukan kegitan tersebut. Pikukuh dan pitutur yang mengatur kegiatan tersebut, juga mengatur tahapan, cara mencapai tujuan, jalan dan hasil yang harus di capainya. Hal ini lahir dari nilai-nilai yang berlaku di masyarakatnya. Aturan dan pikukuh tersebut juga dilingkupi oleh tujuan atau "pancen" baduy yaitu Ngajaga ngareksa nusa teluh puluh telu, Begawan sawidak lima pancer salawe nagara (Menjaga, memelihara nusa puluh tiga, enampuluh lima sungai pusat dua puluh lima nagara) atau memelihara seluruh alam dunia.

Pagawéan barudak dalam proses membuatproduk dan menggunakannya merupakan lingkup kegiatan yang holistik dan menjadi bagian dari semesta yang saling berhubungan danterikat satu sama lainnya. Dengan demikian Proses desain dalam pembuatan pagawean barudak merupakan media transmisi nilai-nilai (pikukuh dan pitutur) melalui keterampilan, sosialisasi dan pendidikan moral.

\section{Daftar Pustaka}

Agus Sachari

2002 Estetika, Makna Simbol dan daya, Penerbit ITB. Bandung

Bangi.Meiyer, J.J.

1891 De Badoej's. Utgegeven Door Het Koninklijk Istituut Voor De Taal, Land - En Volkenkunde Van Nederlandsch-Indie.

Johan Iskandar,

1992 Ekologi Perladangan di Indonesia: Srudi Kasus dari Daerah Baduy Banten Selatan, Jawa Barat. Djambatan. Jakarta
Judistira K.Garna

1987 Tangtu Telu Jaro Tujuh: Kajian Stuktural Masyarakat Baduy di Banten Selatan, Jawa Barat - Indonesia. Fakultas Sain Kemasyarakatan dan Kemanusiaan Universitas Kebagsaan Malaysia.

Papanek, Victor

1992 "The Lesson of Vernacular Architecture, in Green Imperative, Thames in Hudson, New York

Saleh Danasasmita,

1987 Sewaka Darma, Sanghyang Siksakanda Ng Karesian, Amanat Galunggung, Bandung: Departemen Pendidikan dan Kebudayaan.

Jurnal:

Gunggung Senoaji

2011 Prilaku Masyarakat Baduy-Dalam Mengelola Lahan, Hutan, dan Lingkungan di Banten Selatan, Jurnal Humaniora Vol. 23, No.1 Februari 2011.

Masykur Wahid

2010 SUNDA WIWITAN BADUY: Agama Penjaga Alam Lindung di Desa Kanekes Banten Annual Conference on Islamic Studies, Banjarmasin.

\section{Wawancara Narasumber:}

Jaro adat dan Jaro Sami Cibeo 